\title{
Using the Fuzzy Logic in Assessing the Programming Performance of Students
}

\author{
Nihan Arslan Namlı (i) 1,*, Ozan Şenkal ${ }^{1}$
}

${ }^{1}$ The Department of Computer Education and Instructional Technologies, Faculty of Education-Cukurova University, Sarıcam-Adana/TURKEY

\section{ARTICLE HISTORY}

Received: 31 May 2018

Revised: 05 October 2018

Accepted: 12 October 2018

\section{KEYWORDS}

Absolute evaluation system, Flexible percentage system, Fuzzy logic, Programming

\begin{abstract}
The overall objective of this study is to understand how the fuzzy logic theory can be used in measuring the programming performance of the undergraduate students, as well as proving the advantages of using fuzzy logic in evaluation of students' performance. 336 students were involved in the sample of this quantitative study. The first group was consisted of 150 students, whereas the second group was consisted of 186 students. Cluster analysis was also conducted in order to ensure the neutrality of sample. The rule-based intelligent fuzzy logic assessment logic (FLAL) system was developed. This system has a flexible database in order to assess the academic programming performances of students. Therefore, an absolute evaluation system was used in order to calculate the second group's performance. On the other hand, FLAL system was applied to the first group to determine their programming performance. A Mamdani-type fuzzy logic algorithm mechanism having two inputs and one output was utilized. An independent sample $\mathrm{T}$ test was used in analyzing the data sets. As a result, there was a significant difference between first and second groups' results in favor of the first group. While 29 students comprised of $19.3 \%$ of all the students failed in the flexible percentage system, 41 students comprised of $22 \%$ of all the students failed in the absolute evaluation system evaluating their grades via fuzzy logic system. By increasing the input parameters of the fuzzy logic rules, the results can be addressed more efficiently.
\end{abstract}

\section{INTRODUCTION}

The education is one of the most important and difficult matters of society. It has been defined in many different ways. Sönmez (1994) defines the education as the period of changing the behaviors. What education includes is to teach how to learn, assess and evaluate the process. Therefore, the assessment and evaluation are two fundamental components of any education period. Butt (2010) describes both of the assessment and evaluation as the action, which instructors take in order to obtain information about students' skills. The assessment and

CONTACT: Nihan Arslan Namlı $\bigotimes$ nihanarslannamli@egitim.cu.edu.tr $\equiv$ Bilgisayar ve Öğretim Teknolojileri Eğitimi Anabilim Dalı, Eğitim Fakültesi-Çukurova Üniversitesi, Sarıçam - Adana/TÜRKIYE 
evaluation process ensures the progression of learning process of instructors and students (Kerka and Wonacott, 2000). Examining the assessment and evaluation process is important for several reasons. First of all, with the assessment process, the teachers decide what and how students learn (Rockman, 2002). Furthermore, it offers an analysis for classroom management, course guidance, and student support. Under favor of the assessments, the students and teachers receive feedback about their learning, experiences, practices, and performances. It also maintains the quality in measurement of students' efficiency in terms of subjects and method (Kibby, 1999).

It is important to take the significance and requirement of assessment and evaluation into consideration in educational context since they play significant role in both learning and teaching. Almost every teacher makes use of assessment tools in evaluating the academic performances of themselves and students. But, various paradigms emerge out of their diversified assessment methods. Before the constructivist learning approach, the behaviorist and cognitivist approaches dominated the teaching, learning, assessment, and evaluation methods. The teachers generally prefer using the objective tests in order to assess the students because the courses are generally based on conveying the facts and information. Furthermore, what is expected from the student is to memorize only the knowledge in order to make an evaluation (Ward, Stoker \& Ward, 1996). The behaviorist paradigm was replaced by the constructivist approaches, which brought a change in assessment and evaluation processes. Constructivist approach designates varied qualities to knowledge. For instance; being temporary, progressive, and socially and culturally mediated are only some of them (Anderson, 1998).

There are two main approaches used in determining the grades of students. One of these approaches is the Absolute Evaluation System (AES), which uses a fixed standard in which students' performances are determined in accordance with their own peculiar information, competence, and understanding levels (CTL, 2001). In absolute grading system (AGS) used in Turkey, the lecturers assess the grades of students by using the scale that they prepared. The final score of this scale ranges between 0 and 100 points. The points are expressed by using the letters varying between AA and FF. According to AES, the AGS is presented in Table 1.

Table 1. Absolute grading system scale used in Turkey

\begin{tabular}{lll}
\hline Grade & Score & Description \\
\hline FF & $0-25$ & Fail \\
DZ & $0-25$ & Fail \\
DD & $>35$ to 40 & Marginal \\
DC & $>40$ to 50 & Poor \\
CC & $>50$ to 60 & Fair \\
CB & $>60$ to 70 & Good \\
BB & $>70$ to 80 & Very good \\
BA & $>80$ to 90 & Excellent \\
AA & $>90$ & Outstanding \\
\hline
\end{tabular}

The other approach is the Relative Evaluation System (RES), in which the success of student is measured in relation with grades of other students studying in the same class (Keskin and Ertan, 2001). Another approach used is the use of computer-adaptive systems. These are a form of computer-based tests that measure the student's competence level. These instruments that are developed by using FL approaches in evaluation of student's performance have been popularly used (Lin, 2010) for last twenty years. Fuzzy logic approaches includes 0 and 1 as extreme cases of truth (or "the state of matters" or "fact") but also includes the various states of truth in between so that, for example, the result of a comparison between two things could be not "tall" 
or "short" but ".38 of tallness." In general fuzzy approach was proposed to assess student performance based on several criteria which were created several algorithm. Samples can be seen from the literature. Echauz and Vachtsevanos (1995) used FL systems in converting the traditional scores into letter notes. Biswas (1995) proposed a method for evaluating the students by using the FL systems. Chen (1999) improved the Biswas method using the fuzzy sets. Kwok et al. (2001) developed a fuzzy set approach for collaborative assessment in a university. Hammadi and Milne (2003) used the neuro-fuzzy theory in determining the appropriateness of students for the education in an engineering department. In another study carried out by Ertuğrul (2006), the academic performances of academic staff in universities were evaluated via UN approach. Bai and Chen (2008) used the fuzzy logic in generating the concept maps and integrating them into the learning systems in automatized manner. Baba et al. (2009) developed a fuzzy decision-making system software for general use in their study. FL has recently been extensively used in the educational assessment and evaluation process (Rasmani and Shen, 2005, Bai and Chen, 2008; Lin, 2010). An example fuzzy logic decision making scale is seen in Table 2.

Table 2. Fuzzy logic decision making scale

\begin{tabular}{lll}
\hline Grade & Score & Description \\
\hline DC & $>30$ & Poor \\
CC & $>30$ to 45 & Fair \\
CB & $>45$ to 60 & Good \\
BB & $>60$ to 75 & Very good \\
BA & $>75$ to 90 & Excellent \\
AA & $>90$ & Outstanding \\
\hline
\end{tabular}

Reference: Kakoty, S., Lal, M., \& Sarma, S. K. (2012, August)

In Tables 1 and 2, the students' course grades were modified according to the scale that teachers use. If teachers think that AGS is not probably the most suitable tool in measuring the grade of student, then the teacher prefers the fuzzy logic decision making scale created by the teacher. Therefore, it can be concluded that the students' grades can be calculated by using various methods. "Most of the researchers inferred that any suitable study does not exist to measure the perceptive field. 'The fuzzy logic theory' should be called a system, which can eliminate the deficiencies of traditional system" (Semerci, 2004). The deficiencies of traditional system can be listed as: it is not an accurate representation of the performance and the knowledge gained. It is not an exact scoring system:for example the science subject is someone's weak point and with a tremendous effort, he got an $\mathrm{A}$ or a $\mathrm{C}$ for all his attempts, which would have made a vast disparity in his sense of accomplishment.also The traditional letter grade system considers that every alphabet is an inducement to perform good or better or the best. That is why flexible grading system is needed .The current study aims to evaluate the programming performance of students by using the fuzzy logic system (FLS). It was also tried to answer the following subgoals:

1. Evaluating the students programming performance in programming course by using FLS, and

2. Determining the differences between the FLS and AES(Absolute Evaluation System) evaluation logics.

\section{METHOD}

This research is a research in the semi-experimental research model. The only difference between this method and the real experimental method is that the sample is not selected by 
random assignment. In experimental research models, it is tried to determine how systematic changes in the independent variable affect the dependent variable eller (Karasar, 2009).

\subsection{Participants}

The participants ( $n=336 ; 48 \%$ females) were the undergraduate students studying at CEIT (Computer Education \& Instructional Technology) department. The ages of participants were not systematically assessed, since all of the participants selected aged between 17 and 27 years as shown in Table 3.

Table 3. Demographic characteristics of participants

\begin{tabular}{lcc}
\hline Characteristics & $n$ & $\%$ \\
\hline Gender & 336 & 100 \\
Male & 174 & 51.78 \\
Female & 162 & 48.21 \\
Age & 336 & 100 \\
$17-19$ & 214 & 63.69 \\
$20-22$ & 107 & 31.84 \\
$23-27$ & 15 & 4.46 \\
Grade Level & 336 & 100 \\
1 & 71 & 21.13 \\
2 & 63 & 18.75 \\
3 & 169 & 50.29 \\
4 & 33 & 9.82 \\
\hline
\end{tabular}

In the present study, there are two different groups, which are familiar with programming languages. The first one consisted of 150 students whose rankings were calculated with flexible percentage system, whereas the second group consisted of 186 students, whose rankings were calculated using absolute evaluation system.

\subsection{Data Collection and analysis}

The data of first group were collected from the students' grades in homework, projects, midterm exams, final exams, attendance, and their presentations. However, in order to collect the data of second group, only the final and midterm grades were taken into consideration. Two programs used for the statistical analysis were Matlab and SPSS. Independent sample-T test was used in analyzing the data sets.

\subsubsection{Fuzzy Logic Algorithm Mechanism}

According to Mendel, the FLS can be identified as the nonlinear mapping of an input data set to a scalar output data (Mendel, 1995). A FLS can be divided into four segments. These are called fuzzifier (fuzzification), rules, inference engine, and defuzzifier (defuzzification). The general architecture of FLS is presented in Figure 3. 


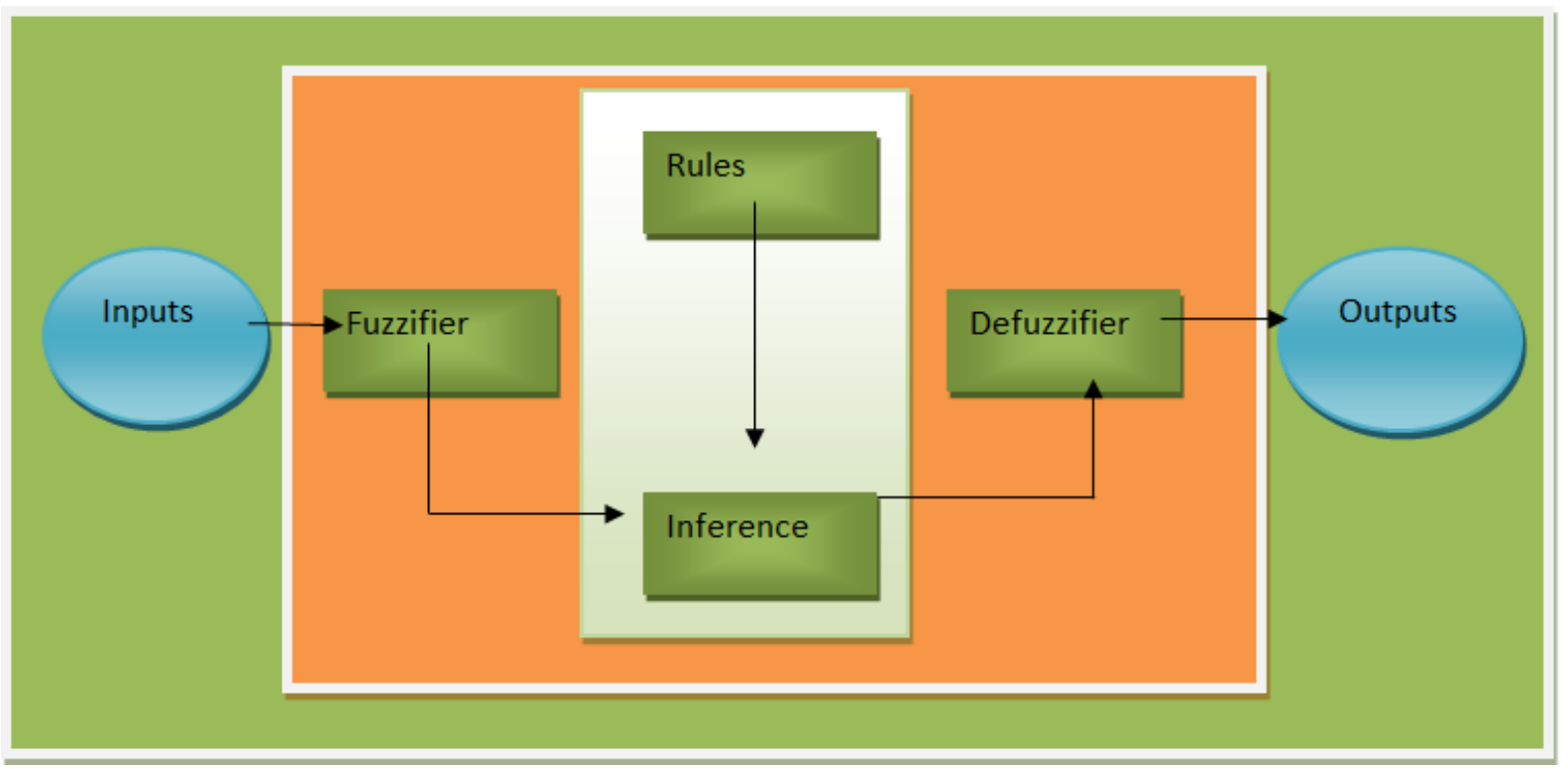

Figure 3. Fuzzy logic system (Tamilselvan and Shanmugam, 2014)

The fuzzy logic system incorporates a process. First of all, the input data are gathered. Then, they are converted into a fuzzy set. During this process, the system uses several fuzzy linguistic variables, fuzzy linguistic terms, and membership functions. The whole of this operation is called fuzzification. Then, an inference constitutes some set of rules. Finally, the resulting fuzzy output matches to a crisp output by using the membership functions in the defuzzification step.

\subsubsection{Fuzzification}

The fuzzification of programming performance was achieved by using both of input variables and membership functions in the fuzzy sets. Every student receives feedbacks about his/her programming grades and attendance into the lesson. These become the input variables of FLS. First input variable is called "mark", and the second one is called "attendance" in this system. The researchers used a flexible percentage system (FPS) for the first group (homework constitutes $15 \%$ of final grade, project $20 \%$, midterm exam $20 \%$, final exam $30 \%$, and presentation $10 \%$ ), and the percentages were degraded into a point system, so that it was easier to calculate the programming grades of students as an input variable for FLS. For the second group, the researchers calculated the grades in accordance with AES (40\% of midterm and 60\% of final exam). After calculating the grades of students, then the grades were entered into FLS as "mark". Moreover, whether the students come to class or not was calculated out of 100 points. If the students' attendance was below $60 \%$, then the final grade was calculated but not taken into consideration. As for the output variable, the parameter showing the overall programming performance of students was named as a "programming performance". As it can be seen in Figure 4, two inputs- one output Mamdani system was used to categorize the data set acquired from both of FPS and AES. 
Membership Function Editor: ITTES 2016

$-\square \times$

File Edit View

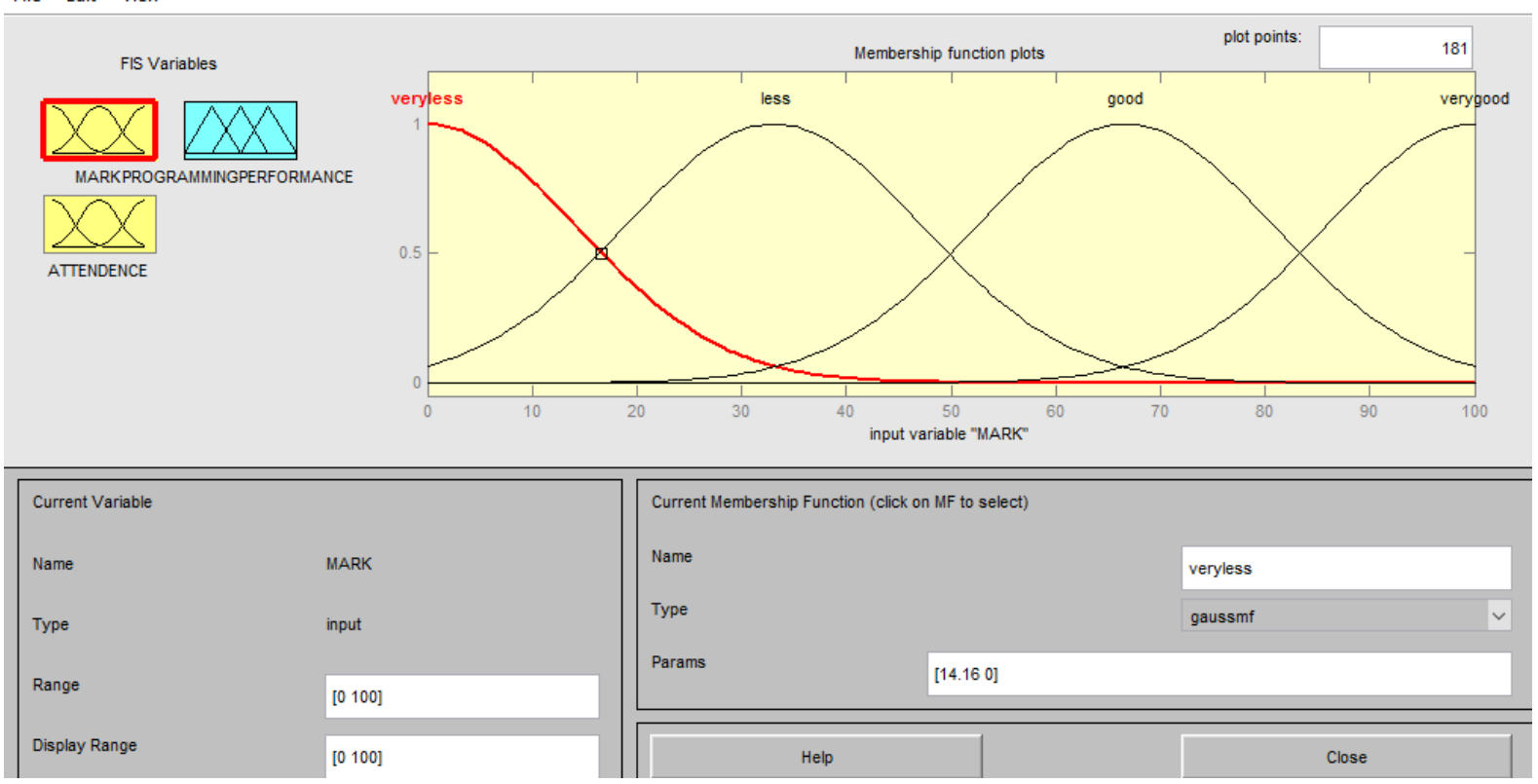

Figure 4. Membership function editor involving two inputs and one output

The input and output variables had four gauss membership functions namely very less, less, good, and very good. An input and output variable was placed in a scale, which was scored between 0 and 100. The membership functions of these input and output variables are also presented in Figure 4.

\subsubsection{Rules and inference}

Some researchers such as Mamdami, Takagi-Surgeno, and Zadeh have developed a series of techniques for the fuzzy decision-making and fuzzy inference, but the Mamdami method was preferred in this research (Semerci, 2004, Zadeh, 1965, Rutkowski, 2004). The rules make use of research's inference process. These rules are non-graphical ones and also are called "IfThen" rules (Altrock, 1995, Semerci, 2004). These rules were constituted from the perspective of obtaining ideas from Computer Education and Instructional Technologies, computer engineering, and biomedical engineering experts in order to determine how the FLS makes a decision according to the importance of the inputs and output in order to determine the membership functions of FLS results (Figure 5). 


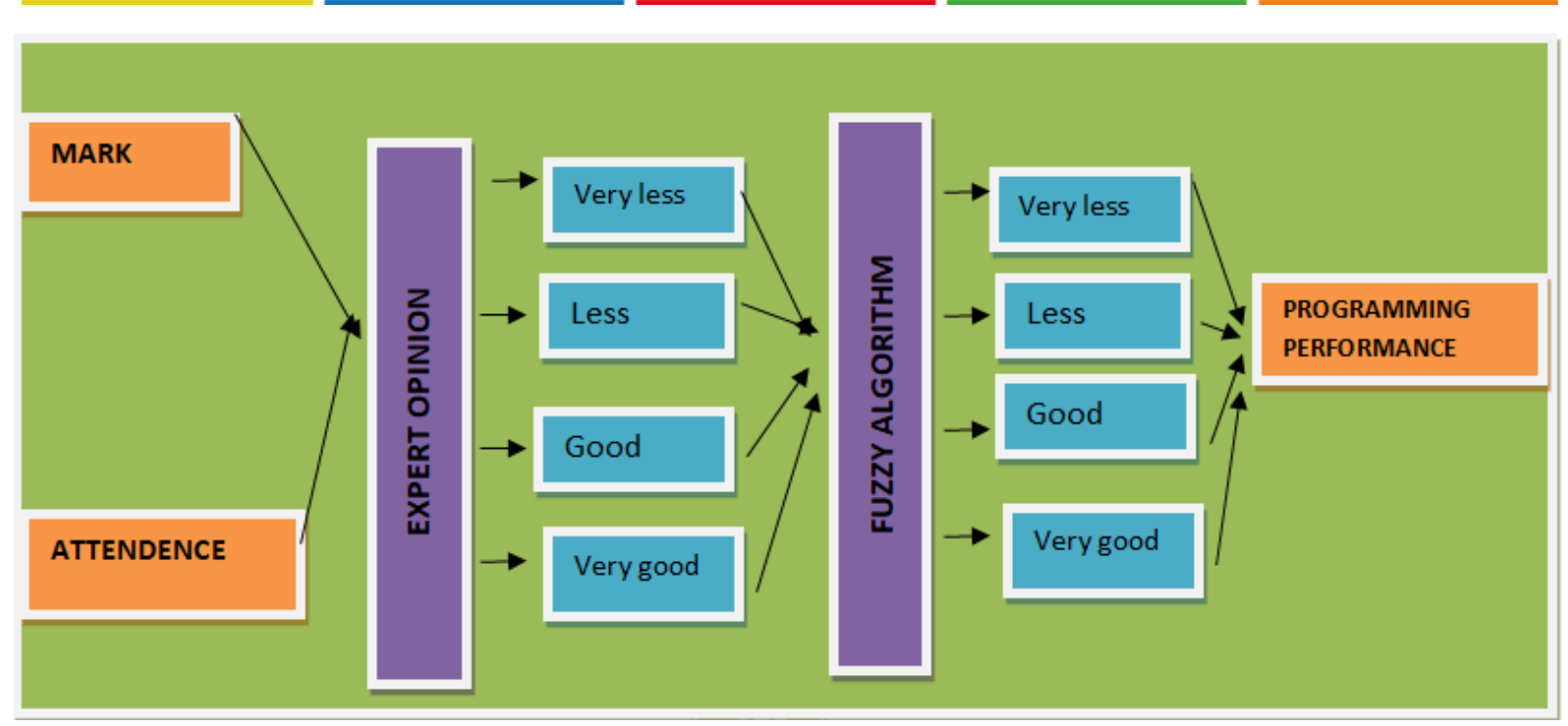

Figure 5. Fuzzy logic algorithm with expert opinion

Fuzzy rules for assessing students' performance in Fig. 6 are listed below.

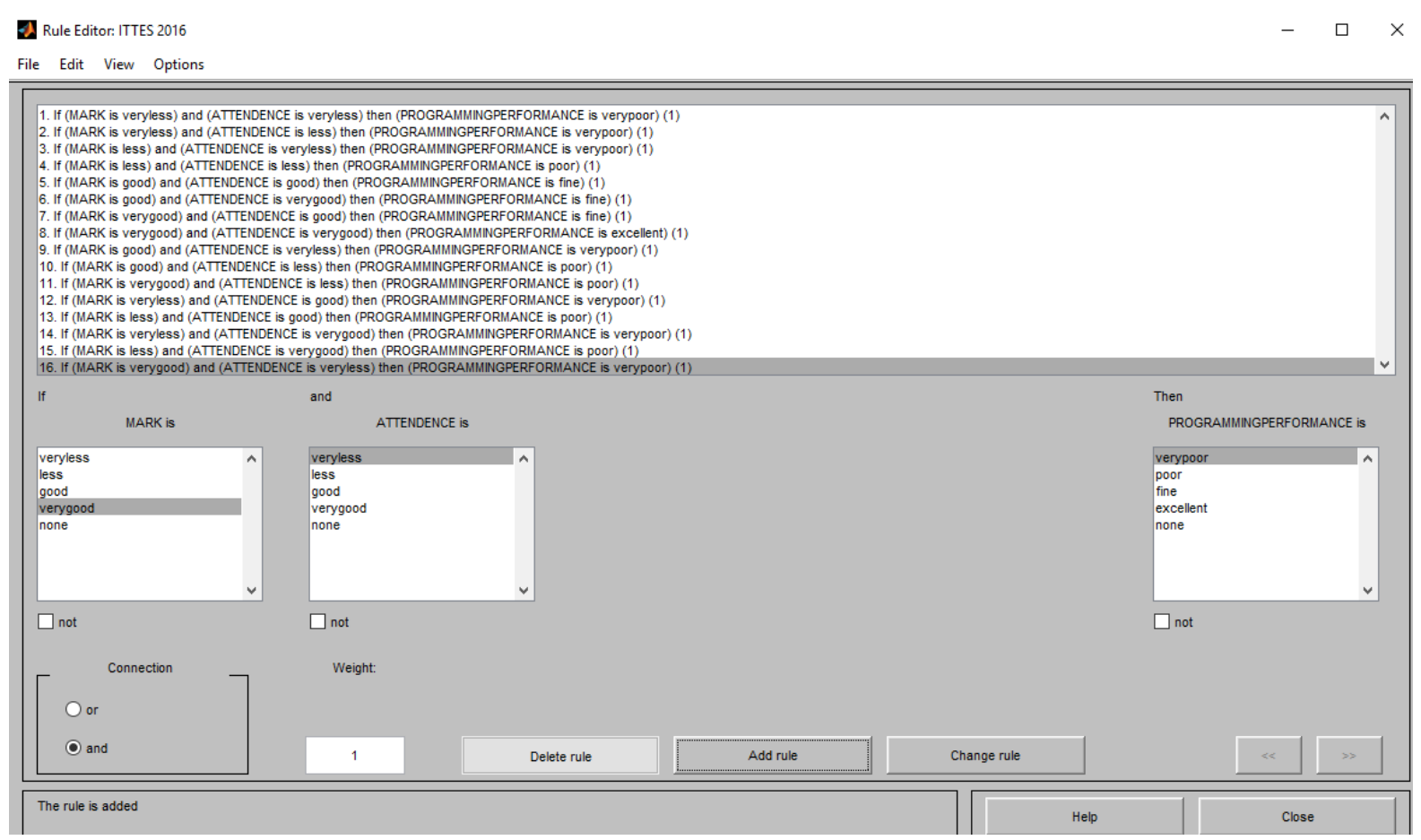

Figure 6. Rule editor

In FLS, a rule base was constructed in order to control the output variable. When one rule was active, an AND operation was carried out between the inputs. This method was repeated, so that the output membership functions were determined for each rule. A fuzzy rule is a simple If-Then rule with condition and conclusion. For instance; Rule-2: If (MARK is very less) and (ATTENDENCE is less) then (PROGRAMMING PERFORMANCE is very poor).

\subsubsection{Defuzzyfication}

Following the rules and inference step, the final result became the fuzzy value. This result should be defuzzified in order to obtain the final output. The final output is the main aim of the defuzzifier component of FLS. The defuzzification was executed in accordance with the 
membership function of output variable. The example of a student's rules and performance value is presented in Figure 6.

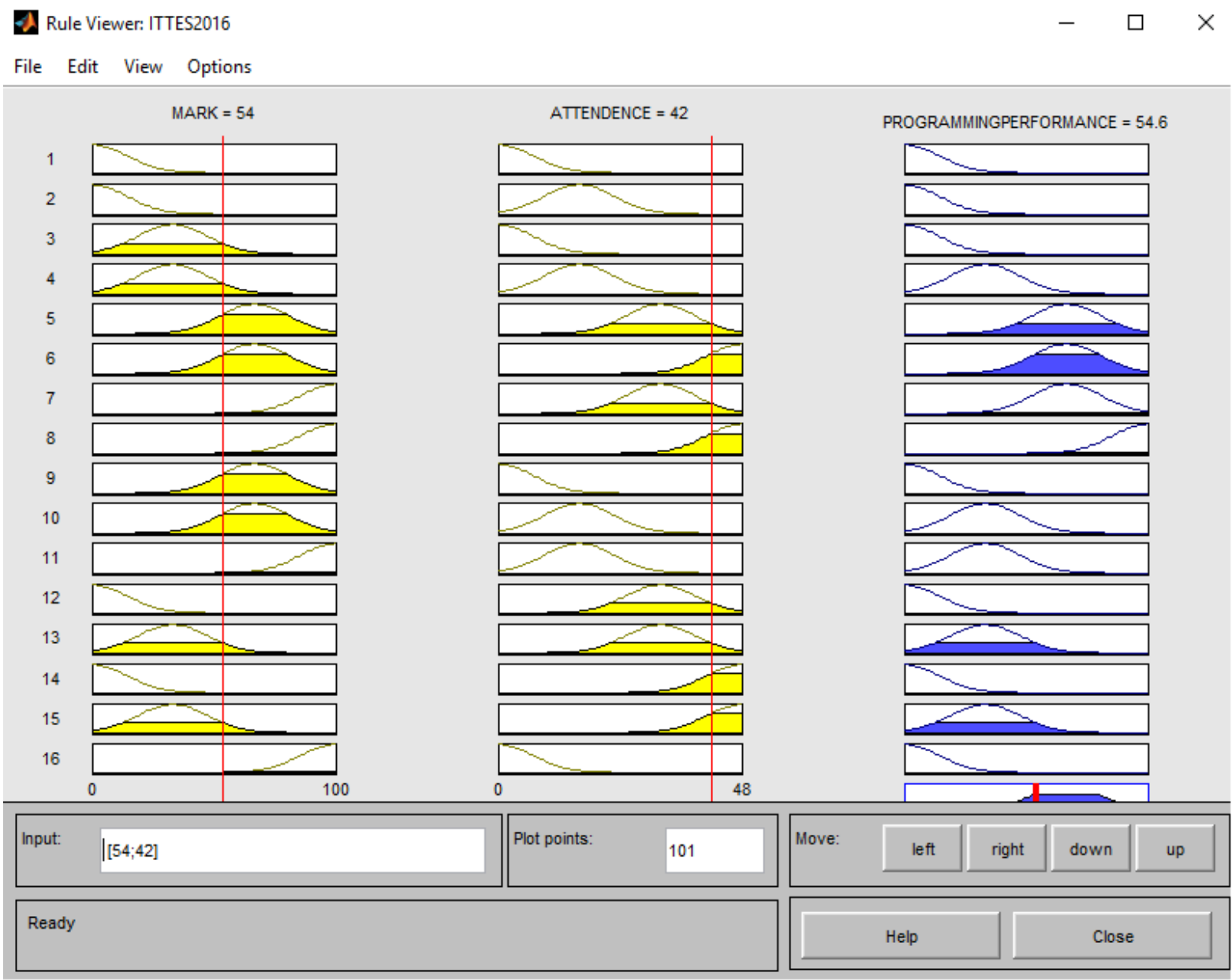

Figure 7. Example of the rules and performance value

The result was defuzzificated in accordance with the Mamdani method. The area between input and output axes of membership function is shaded in accordance with the accuracy of rules. One of the student's results in this deffuzifier is shown in Figure 7. The surface view of students is also presented in Figure 8. 
Surface Viewer: ITTES2016

File Edit View Options

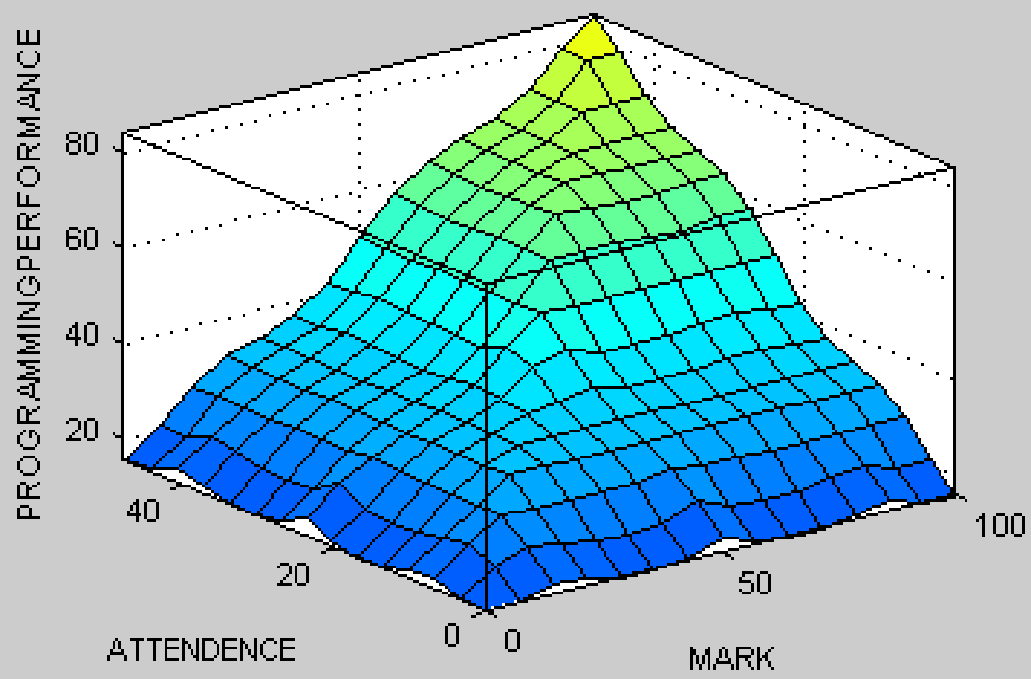

\begin{tabular}{|c|c|c|c|c|c|c|}
\hline$X$ (input): & MARK & $\checkmark$ & $Y$ (input): & ATTENDENCE $\checkmark$ & Z (output): & PROGRAM... $\vee$ \\
\hline $\mathrm{X}$ grids: & 15 & & $Y$ grids: & 15 & & Evaluate \\
\hline
\end{tabular}

\begin{tabular}{|l|l|l|l|l|l|l|l|l|}
\hline Ref. Input: & Help points: 101 & Close \\
\hline
\end{tabular}

Ready

Figure 8. Surface view

\section{RESULTS}

The results of first and second groups (Tables 4 and 5) and experts' perspectives were added into the FLS (Figure 5.)

\subsection{Datasets obtained from two groups for comparing their FLS weights}

The independent T-test results of FLS grades using two different groups' calculation are shown in Table 4.

Table 4. Independent T-test FLS results of the two different groups

\begin{tabular}{llllll}
\hline Study Group & $\mathrm{N}$ & Mean & SD & $\mathrm{t}$ & $\mathrm{p}$ \\
\hline 1. Group (FPS) & 150 & 51.76 & 21.90 & 4.62 & .000 \\
2. Group(AES) & 186 & 39.77 & 17.00 & & \\
\hline
\end{tabular}

As it can be seen in Table 4, the mean score of first group was calculated to be $X=51.76$, and that of second group was found to be $X=39.77$ (Table 5). A significant difference in favor of the first group was found between them $\left(X_{\mathrm{FPS}}=51.76, \mathrm{X}_{\mathrm{AES}}=39.77 \mathrm{t}=4.62 ; \mathrm{p}<0.05\right)$.

Moreover, it can be seen that the second group was successful less than the first group was. The findings related to the comparisons of the AES and FPS performance based on FLS are presented in Table 5. 
Table 5. Comparisons of students' AES and FPS programming performance grades according to AGS and FLS

\begin{tabular}{lllllllll}
\hline Stu. No & $\begin{array}{l}\text { Stu. } \\
\text { Marks }\end{array}$ & $\begin{array}{l}\text { Stu. } \\
\text { Attendance }\end{array}$ & $\begin{array}{l}\text { 1.group } \\
\text { Performa } \\
\text { nce } \\
\text { (FPS) }\end{array}$ & $\begin{array}{l}\text { Final } \\
\text { Grade of } \\
\text { 1. Group } \\
\text { (FLS) }\end{array}$ & $\begin{array}{l}\text { Final } \\
\text { Grade of } \\
\text { 1. Group } \\
\text { (AGS) }\end{array}$ & $\begin{array}{l}\text { 2.group } \\
\text { performa } \\
\text { nce } \\
\text { (AES) }\end{array}$ & $\begin{array}{l}\text { Final } \\
\text { Grade of } \\
\text { 2. group } \\
\text { (FLS) }\end{array}$ & $\begin{array}{l}\text { Final } \\
\text { Grade of } \\
\text { 2. Group } \\
\text { (AGS) }\end{array}$ \\
\hline 1 & 91 & 46 & 65.70 & DZ & DZ & 73 & DZ & DZ \\
2 & 89 & 78 & 77.80 & BA & BB & 84.6 & BA & BA \\
3 & 54 & 44 & 44.19 & DZ & DZ & 50 & DZ & DZ \\
4 & 91 & 50 & 50.11 & DZ & DZ & 74.6 & DZ & DZ \\
5 & 55 & 86 & 54.80 & CB & CC & 67.4 & BB & CB \\
6 & 95 & 93 & 79.27 & BA & BB & 94.2 & AA & AA \\
7 & 41 & 94 & 70.60 & BB & CB & 68.2 & BB & CB \\
\hline
\end{tabular}

In Table 5, the performance grades of first and second groups are presented. Here, $\mathrm{S}$ The same procedure was applied for the second group. As a result, 29 students (19.3\% of the total) have failed in group 1, whereas 41 students ( $22 \%$ of total) have failed in the group 2 . After the results were scored, it became easier to determine the difference between the group 1 and 2 .

\section{DISCUSSION and CONCLUSION}

There are two complementary components in an educational process, namely the assessment and evaluation. Assessment is the systematic process of documenting and using empirical data on the knowledge, skills, attitudes and beliefs. By taking the assessment, teachers try to improve student learning. On the other hand, evaluation focuses on grades and may reflect classroom components other than course content and mastery level. Evaluation is a final review on your instruction to gauge the quality. The assessment and evaluation are performed at the end of every semester. It is predicted to find many areas of use in education systems, as well as the evaluation of student academic performance, including the curricula, teachers, educators, instructors, and lecturers (Bai \& Chen, 2006; Pavani, Gangadhar \& Gulhare, 2012; Rasmani \& Shen, 2006). In the evaluation of students' academic performance, the fuzzy logic supplies new techniques that have been used for evaluation depending on the numeric data acquired in assessment and evaluation of exam marks (Rasmani \& Shen, 2006).

So, this research presents the integration of fuzzy logic into assessment of students' programming performance grades. In this context, the new FLS has proposed an evaluation system based on fuzzy logic techniques for the students' programming performance. When the results are evaluated by using a fuzzy-expert system, the differences are observed between the outcomes of AES and proposed fuzzy logic-based expert systems. The EAGS (existed absolute grading system) adheres to the stable mathematical rules. On the other hand, the evaluation via FLS offers excellent flexibility and reliability. In this research, two groups of FLS results were shown and a comparison was made between the AES and FPS grades determined in accordance with AGS and FLS. As a result, the grades of some students decreased, but those of some others increased and there was no visible change in some of them (Özdemir \& Tekin, 2016). Moreover, there was a significant difference in favor of the FPS. When compared to AES, it was seen that the proposed method, which was the fuzzy logic system, was more appropriate for evaluating the academic performance of students. This result is in parallel with those reported by Gawronski (1971), Çekiç (1991), Bowers (1987), and Kılıç (2002).

It can be concluded that this system can be useful in analyzing the performance of students by making use of membership functions. The improvement methodology can be applied to those students listed in the performance categories of "poor" or "very poor". It should be noted that 
this improvement methodology varies between the universities. In the future, C-Means clustering algorithm can be suggested for students' academic performance evaluation because C-means clustering algorithms are qualified to generate and separate the membership function. This makes it easier to find experts for getting their opinion while preparing membership functions. Moreover, the dynamic fuzzy expert system can be developed in order to achieve quick feedback information about the overall performance of the student.

\section{ORCID}

\section{Nihan ARSLAN NAMLI (D) http://orcid.org/0000-0002-5425-1468}

\section{REFERENCES}

Altrock, V., C. (1995). Fuzzy Logic Applications in Europe, In J. Yen, R. Langari, and L. A. Zadeh (Eds.) Industrial Applications of Fuzzy Logic and Intelligent Systems, Chicago: IEEE Press.

Anderson, R. S. (1998). Why Talk About Different Ways to Grade? The Shift from Traditional Assessment to Alternative Assessment, New Directions for Teaching and Learning, (74), 5-16.

Baba, A. F., Kuşcu, D., \& Han, K. (2009). Developing a software for fuzzy group decision support system: A case study. The Turkish Online Journal of Educational Technology, TOJET, 3(8), 22-29.

Bai, S. M., \& Chen, S. M. (2008). Automatically constructing grade membership functions of fuzzy rules for students' evaluation. Expert Systems with Applications, 35(3), 14081414.

Biswas, R. (1995). An application of fuzzy sets in students' evaluation. Fuzzy Sets and Systems, 74, 187-194.

Bowers, P.S. (1987). The Effects of the 4MAT System on Achievement and Attitudes in Science. Unpublished PhD thesis, The University of Noith Caroîina at Chapel Hill.

Butt, G. (2010). Making Assessment Matter, NewYork, USA: Continuum International Publishing Group.

Chen, S. M. (1999). Evaluating weapon systems using fuzzy arithmetic operations. Fuzzy Sets and Systems, (77), 265-276.

CTL, (2001). Teaching at Carolina. Center for Teaching and Learning, University of North Carolina at Chapel Hill. Retrieved 2 February, 2018 from http://ctl.unc.edu/he2.html

Çekiç, H. (1991). Matching learning and teaching styles in a Turkish EFL university classroom and its effect on language development. Unpublished master thesis, Bilkent Üniversitesi, Ankara

Echauz, J. R., \& Vachtsevanos, G. J. (1995). Fuzzy Grading System. IEEE Transactions on Education, 38(2), 158-165.

Ertuğrul, İ. (2006). Akademik performans değerlendirmede bulanık mantık yaklaşımı. Atatürk Üniversitesi İ̈BF Dergisi, 20(1), 155-156.

Gawronski, J. D. (1971). An investigation of the effect of selected learning styles on achievement in eighth grade mathematics. Unpublished $\mathrm{PhD}$ thesis, University of Minnesota.

J. Mendel. Fuzzy logic systems for engineering: a tutorial. Proceedings of the IEEE, 83(3), 345377.

K. A. Rasmani \& Q. Shen (2006). Data-Driven Fuzzy Rule Generation and its Application for Student Academic Performance Evaluation. International Journal of Applied Intelligence, 25(3), 305-319.

Karasar, N. (2009). Bilimsel araştırma yöntemi. Ankara: Nobel Yayın Dağıtım. 
Kerka, S., \& Wonacott, M.E. (2000). Assessing learners online: Practitioner file. Washington, D.C.: Office of Educational Research and Improvement.

Keskin, M. \& Ertan, H. (2001). İstanbul Üniversitesi'nin Bağıl Değerlendirme Sistemi, İstanbul.

Kılıç, E. (2002), Web temelli ögrrenmede baskın ögrrenme stilinin ögrenme etkinlikleri tercihi ve akademik başarıya etkisi. Yayınlanmamış doktora tezi, Ankara Üniversitesi, Ankara.

Kibby, M (1999). Assessing Students On-line. The University of Newcastle Retrieved June 3, 2008, from http://www.newcastle.edu.au/discipline/sociolanthrop/staff/kibbymarj/onli ne/assess.html

Kwok, R. C.W., Ma, J., Vogel, D., \& Zhou, D. (2001). Collaborative assessment in Education: An application of a Fuzzy GSS. Information Management, 39, 243- 253.

Lin, H. F. (2010). An application of fuzzy ahp for evaluating course website quality. Computers \& Education, 54(4), 877-888.

Özdemir, O., \& Tekin, A. (2016). Evaluation of the presentation skills of the pre-service teachers via fuzzy logic. Computers in Human Behavior, 61, 288-299.

Rasmani, K. A., \& Shen, Q. (2005). Subsethood-Based fuzzy rule models and their application to student performance classification. IEEE International Conference on Fuzzy Systems.

Rockman, I. F. (2002). The importance of assessment, Reference Services Review, 30(3), 181182.

R.S. Yadav, S. Kumar (2009). The Effective Utilizations of Fuzzy Logic Approach for Student Academic Performance Evaluation. M.Phil. Dissertation, YCMOU, Nashik, India, 6-7.

Rutkowski, L. (2004). Flexible Neuro-Fuzzy Systems: Structures, Learning and Performance Evaluation, Bostan: Kluwer Academic Publisher.

Semerci, Ç. (2004). "The Influence of Fuzzy Logic Theory on Students' Achievement." TOJET: The Turkish Online Journal of Educational Technology, 3, 2.

Bai, S.M. \& Chen, S.M. (2006). A new method for students' learning achievement evaluation using fuzzy membership functions. Proceeding of the 11th Conference of Artificial Intelligence and Applications, Kaohsiung, Taiwan, Republic of China, 177-184.

Sönmez, V. (1994). Program geliştirmede öğretmen el kitabı, Ankara: PEGEM Yayınları. No:12, 7. Basim.

Pavani, S. Gangadhar, P.V.S.S., \& K. K. (2012). Gulhare. Evaluation of Teacher's Performance Evaluation Using Fuzzy Logic Techniques. International Journal of Computer Trends and Technology, 3(2), 200-205.

Tamilselvan, G. M., \& Shanmugam, A. (2014). "Fuzzy-Logic Based Medium Access Control Model for Battery Lifetime Enhancement in Wireless Body Area Networks." Journal of Engineering and Technology 4(2), 135.

Ward, A., Stoker, H. W., \& Murray-Ward, M. (1996). Educational measurement: Origins, theories, and explications Volume 2. Maryland: University Press of America

Wu, M. H. (2003). Research on applying fuzzy set theory and item response theory to evaluate learning performance. Master Thesis, Department of Information Management, Chaoyang University of Technology, Wufeng, Taichung County, Republic of China.

Zadeh (1965). "Fuzzy sets. Information and Control”, (8), 338-354. 